\title{
Lee Ufan, the Hidden Face of the Moon
}

\section{Rye Dag Holmboe}

The matter is neither of explaining nor of defining but only of describing.

Roland Barthes, The Neutral (1978)

A rock tilts towards the centre of a large steel plate that curves across the exhibition space. Lit from above, it casts a shadow of itself against the floor, its outline as sharply edged as a stencil. Between the rock and the steel lies empty space, but the position of the two elements - the rock leaning forward, the steel concave and receptive-produces a kind of magnetic field that attracts as much as it repels, animating empty space and making it vibrate.

Lee Ufan's Relatum - Counterpoint (2016) is one in a series of works in which rocks and steel, and sometimes rope, mirror, and cotton, are placed in different configurations that enter into dialogue with their environment and the spectator's body. The word 'relatum' is used in philosophy and logic to designate each of the terms between which a relation exists. Accordingly, as important as the material qualities of the elements in Lee's works are the relations they enter into, and the often theatrical and minutely choreographed situations they produce. The placement of each term in the Relatum series is just so, and the slightest change, in the inclination of a rock, say, or in the steel's curvature, would alter the experience of the work dramatically. Every element exists in its relations to every other element, and it is in these interactions, interactions in which no term—steel, rock, body, space — is privileged above any other, that the experience of the works resides.

Lee's interest in materials such as steel and rock can be traced to his involvement in Mono-ha, or School of Things, a movement formed in Japan in the late 1960s. (Born in 
Korea in 1936, the artist moved to Japan twenty years later, and has since spent his life between Tokyo and Paris.) The artists associated with Mono-ha, which included Susumu Koshimizu, Sekine Nobuo, and Suga Kishio, produced art with basic materials such as stone, cotton, steel, and wood, and employed strategies that required only minimal intervention. In this way, the artist's will and ego were held in check, while materials were allowed to express their inherent properties. This approach was partly developed in response to the rapid modernisation and industrialisation of Japan in the post-war period, the movement's principle aim being to envisage different, non-hierarchical relations between the natural and the manmade. Thus, unlike the artistic strategies of Gutaï — a term that literally means 'concreteness' - a group of artists whose works from the mid-1950s often privileged the gestural and expressive, and whose ethos was confrontational and sometimes destructive, the artists associated with Mono-ha worked according to principles of thesis and antithesis. Unconcerned with overt provocation, they tried to turn both the making and the experience of art towards notions of process and affect, or what Lee would call 'encounter.' ${ }^{1}$ Sekine's Phase-Mother Earth (1968), for example, a work that is often seen to mark the beginning of Mono-ha, was made by digging out a cylinder of earth over two metres deep, which was then mixed with concrete and shaped into a cylinder of the same size, only for the hole to be filled in at the end of the exhibition. The various phases did not cancel each other out so much as produce a tension between making and unmaking, the purposeful and the purposeless, while also offering a reflection on topology and the continuity between art and world, which here act upon each other mutually, so that action cannot be said to originate in either. A similar claim could be made for Susumu's Paper (1969), a large block of granite wrapped in a sheet

\footnotetext{
${ }^{1}$ See: Lee Ufan, The Art of Encounter, ed Jean Fisher, trans Stanley N. Anderson, Lisson Gallery, London, 2008. The title of my essay is adapted from Claude Levi-Strauss's collection of essays on Japan, The Other Face of the Moon. I would like to express my gratitude to Lee Ufan and Esra Joo for their very generous invitation to research Lee's work in Korea and Japan in the summer of 2017, a trip that was crucial to the development of this essay. Thanks also to Lee for an invaluable conversation, which also informed me of his interest in Marcel Proust.
} 
of handmade paper, which spectators were allowed to touch and peer into. Paper in this work does not function as a material support for drawing or painting, but acts instead as an envelope whose fragility is emphasised by the hardness of the object it contains, and vice versa. The juxtaposition enables paper to become paper, so to speak, and for stone to become stone, while personal or individual expression is elided.

Lee's Relatum - Counterpoint shares many similarities with works the artist made during this period. Earlier iterations of the series, which were all renamed Relatum in 1974, also play on contrasts between materials, placing special emphasis on the relationship between the industrial and the natural, even as they work to neutralise such oppositions, granting the human world and the world of inert or living matter equal importance. For instance, to make Relatum (formerly Phenomenon and Perception), a work first produced in 1968 and reproduced in 2010, Lee dropped a rock from a small height onto a square mirror laid over a steel plate. By allowing the force of gravity to form part of the creative process, the result was opened to chance and the artist's subjectivity was eclipsed, the cracks in the mirror coming to resemble a form of automatic drawing. In another work, also made in 1968, the edges of a large steel cube were covered in thick white cotton. The different elements act in antithetical domains - the effect is comical and nothing short of absurd, a parody perhaps of the modernist cube and its purported rationality-yet they also become counterparts of each other, the natural and the industrial held in a state of dynamic reciprocity. A similar claim could be made for another early work in the series, produced in 1970, where two Lshaped steel plates, each sixty centimetres high, echo the corners of the room in which they are displayed, creating an intimate connection between sculpture and architecture, while also drawing attention to an area of the room that would normally be overlooked. Comparable relations are set up and enacted in later iterations such as Relatum-Counterpoint, the main 
difference being that the installations, or what Lee would call 'structures, ${ }^{2}$ become increasingly theatrical - the artist has described the various elements in the series as sharing 'the reciprocal relationship of actors in a play' ${ }^{3}$ — and open to the spectator's movements.

The term 'counterpoint' is used in music to describe the combination of different voices or melodies into a single harmonic texture where each element, though inter-reliant, maintains its own rhythm and contour. The term provides a fitting way of thinking about Lee's works, and it is significant that he has often described them in musical terms. In particular, the artist has cited the Japanese composer Toru Takemitsu as an important reference point because of his uses of silence, a modality of sound that is active in Toru's compositions and does not function merely as a background against which music is heard. This is how empty space is experienced in Lee's work, as a plenum and not a vacuum. It is also noteworthy that, in addition to an interest in Japanese $m a$, 'the unsounded part of [musical] experience, ${ }^{4}$ as Toru defines it, the composer described his own appreciation of traditional Japanese music as having been triggered and mediated by the chance procedures of John Cage and the latter's interest in Zen, as well as his use of graphic scores, where sounds find spatial expression. There is a comparable sense of cultural hybridity to Lee's work. The juxtaposition of natural and industrial materials in Relatum-Counterpoint might be compared to tendencies in Land Art, Minimalism, or Post-Minimalism, the use of steel especially reminiscent of Richard Serra's large-scale installations, where steel plates constrain and determine the spectator's movements, a comparison returned to. Meanwhile, the presence of natural materials in Lee's work is also evocative of, for example, traditional gardens in Japan, such as the highly stylised fifteenth century garden in the Ryoan-ji temple

\footnotetext{
${ }^{2}$ Lee, The Art of Encounter, op cit, p 40

${ }^{3}$ Ibid, p 46

${ }^{4}$ Toru Takemitsu, 'A Single Sound', Confronting Silence: Selected Writings, The Scarecrow Press, Lanham, Maryland, 1995, p 51
} 
in Kyoto, where fifteen rocks are laid out on immaculately tended gravel. Whatever the vantage point adopted, it is impossible to see more than fourteen of the stones at once, pointing towards the limits of knowledge. The same might be said of Lee's paintings, which evoke, but also refuse, the gestural spontaneity of Abstract Expressionism, and which, as Joan Kee has observed, are also evocative of Korean munjado, a form of calligraphy where gesture and the materiality of line work against the demands of representation. ${ }^{5}$ The strokes of paint in From Line (1978), for instance, a work that belongs to a series of the same name, are emptied of symbolic content. To make the painting, Lee loaded a brush with blue paint made out of a mixture of powdered cobalt and animal-skin glue and covered the surface of the canvas with a set of twenty-six downward strokes, each gradually fading as it reaches the bottom edge. The density of each stroke is determined by the amount of paint on the brush, while the number of lines is decided by both the size of the brush and the width of the canvas. If Abstract Expressionist painting is conventionally seen as an exemplar of the high modernist trope of self-expression, gesture in From Line can be said to work towards the self's effacement. The role of decision-making is minimised, constrained by the inherent properties of brush, canvas, and paint, while the artist's body is turned into a kind of conduit: the painting of each stroke occurs almost automatically, without the need of a controlling or reflecting intelligence.

Of course, the point is not to suggest that Lee's works offer a simple, or indeed a complex, resolution of Western and Eastern traditions. To know what something is like is to know that thing in terms of what it is not, and the differences are more important than any formal similarities. To return to the example of Serra, it is said that the artist's interest in the

\footnotetext{
${ }^{5}$ Joan Kee, 'Points, Lines, Encounters: The World According to Lee Ufan', Oxford Art Journal, vol 31, no 3, 2008, pp 405-424, p 420. Lee's paintings also recall the stamped markings on Buncheong ceramics from the Joseon dynasty in $15^{\text {th }}$ century Korea, many of which were appropriated by Japan during the colonial rule (1910-1945).
} 
ambulatory experience of sculpture was triggered by a visit to Japan in the 1970s, where he was especially taken by the Zen gardens of Myoshin-ji. This was one of the reasons why Yve-Alain Bois interpreted his work through the lens of the picturesque: not because it transforms the world into a picture, however, which is how the picturesque is usually understood, but because it reveals the potentials of a given site and accords special importance to the spectator's movements. ${ }^{6}$ Yet Serra's works are intransigent and dissonant, if not confrontational. The large steel plates operate as cuts in space, leading to a sense of indeterminacy or 'formlessness, ${ }^{, 7}$ to use Bois' term, even as they retain an unlikely grace or precarious, balletic poise. The underlying premise of this interpretation, indebted to the writings of Georges Bataille, is threefold: that underlying artistic form are processes entropic in character; that the world is composed of crude, volatile matter that precedes form; and that there is an absence of pattern, that is to say, no unifying field. Lee's work intimates another modality of experience, as well as a different understanding of the aesthetic. This is partly because it includes natural materials in its compositions, which indicates that, for Lee, as for the other artists associated with Mono-ha, art need not be limited to what is made by human beings or machines. No less distinctive, however, is the way in which his work is more emphatically concerned with the lateral axis and with the interstices between things. To walk among the elements in the Relatum series is to find one's movements choreographed in such a way that one enters into an affinitive, perhaps mimetic, relationship with the work, adopting its characteristics as one's own. Thus, in Relatum - Counterpoint, the body forms part of the work's harmonic texture, while the experience of Relatum - Silence (2008), where a rock is placed opposite a rectangular steel plate that rests against a wall, is one of quietude. The

\footnotetext{
${ }^{6}$ Yve Alain-Bois, 'A Picturesque Stoll around 'Clara-Clara', October, vol 29, summer, 1984, pp 32 62

${ }^{7}$ For an examination of Serra's work in relation to perceptual cuts, see Rosalind Krauss, 'Richard Serra, a Translation', The Originality of the Avant-Garde and Other Modernist Myths, MIT Press, Cambridge, Mass., 1983, pp 261-274
} 
properties of the materials are not changed, only the relations they enter into. What an encounter with the works share is an experience at once decentred and continuous: the body becomes the ground of sculptural experience, both existential and perceptual, and enters into a field of reciprocity that reconfigures, non-hierarchically, the relation between subject and object, the made and the unmade. Meanwhile, if Serra's sculptural installations are anthropomorphic, sometimes bearing human names such as Clara, the animistic and theatrical qualities of Lee's works are different. For example, in Relatum - Discussion (2003), four rocks sit around a square steel plate laid flat on the ground, giving the impression that a silent conversation is taking place, the contents of which are never disclosed. In another work, suggestively titled Relatum - He and She (2005), a rock seems to gaze amorously at a raised lip of steel, which here becomes almost flesh-like. This confusion of the animate and inanimate is highlighted in photographic documentation. In an image taken in 1978 of a work exhibited on the banks of the Seine in Paris, two rocks nearly touch, echoing a couple standing by the river looking out into the distance. In another photograph, taken by Lee himself, the artist's granddaughter sits next to a rock with her back to him. It is as if the rock were her double, or she the rock's. Such consonances are made possible by Lee's artistic approach, which, when compared to Serra's, and as both artists have independently observed, is decidedly less interventionist. It is a matter of "nudging something which already exists so that the world shows up more vividly, ${ }^{8}$ as Lee put it. It is as if the works in the Relatum series manifested a reality that sought only to find expression: that of relationality. ${ }^{9}$

In advanced capitalist societies, the subject's relationship to the object-world tends to be defined by use or exchange, while nature is instrumentalised: it is imagined as an object

\footnotetext{
${ }^{8}$ Lee, The Art of Encounter, op cit, p 54

${ }^{9}$ Writing on Serra's monumental steel sculptures, for example, Lee describes how they successfully 'create another reality' and overwhelm the person standing before them with 'a sense of strangeness and brute silence.' Lee, 'Richard Serra' (2000-01), in The Art of Encounter, op cit, p 65
} 
for, and instrument of, the human will. The very category of the subject thus has inscribed within itself a particular conception of the object as subservient. Lee's works undo such hierarchies. In so doing, they also raise important questions concerned with how we think about animism and the lives of things, whether natural or industrial. One tendency is to understand the issue through the lens of commodity fetishism. In a famous chapter of Capital (1889), Karl Marx offered a vivid description of the ways in which money animates objects as ordinary as a wooden table and converts them into strange, 'supra-sensible' things filled with 'theological niceties.' ${ }^{10}$ According to this narrative, money spiritualises inanimate matter and engenders a toing-and-froing between the material and immaterial, which is understood as a mystification. The subject is then pitched against an alien and duplicitous object-world, and it is the function of critique to penetrate those illusions and restore the world to its truth. It was for similar reasons that, in an exchange with Theodor W. Adorno about his own essay 'The Paris of the Second Empire in Baudelaire' (1938), Walter Benjamin observed that in capitalist modernity empathy with the inorganic constituted a disguised form of empathy with exchange-value. ${ }^{11}$ To make sense of this claim, think of a status symbol, where people identify with the price they have paid for the object more than its material qualities. Yet this abstract and almost uncanny experience of the commodity, which sometimes reads like Gothic fiction — a genre that itself arose from within capitalism and, arguably, the money form — does not adequately describe the experience of Lee's work. ${ }^{12}$ This is not to deny its implication in the market. It would simply be reductive to see the indistinction between subject and object in the Relatum series as symptomatic of a generalised condition of reification, wherein relations between people, mediated by money,

\footnotetext{
${ }^{10}$ Karl Marx, Capital: A Critique of Political Economy, vol 1, Ben Fowkes, trans, Harmondsworth: Penguin \& New Left Review, London, 1976, p 163

${ }^{11}$ Walter Benjamin, Selected Writings, 1938-1940, 'Exchange with Adorno on "Paris of the Second Empire"', Edmund Jephcott et al, trans, volume 4, p 111

${ }^{12}$ For a discussion of the relation between the Gothic and Marx, see, for example, David McNally, Monsters of the Market: Zombies, Vampires and Global Capitalism, Brill, Laiden, 2011
} 
must appear as things, or to view the animistic aspects of the works as an indication of fetishism, the 'secret of the commodity, ${ }^{13}$ in Marx's expression. The situations his works produce create a distinct set of relations. In an early essay on the basic tenets of Mono-ha, Suga called for the 'elimination of the sadistic tendency to turn [a thing] into something unique by making it over anew.' 14 The point was that, by changing the material properties of things as little as possible and by opening works to the possibility of future iterations, things might be able to express their own properties and so enjoy a form of agency different in character to objects of use or exchange. The idea is not without precedent. Almost half a century earlier, the Russian Constructivists also tried to overcome the subject's mystified and fetishistic relation to the commodity, not by eliminating material objects, but by reconfiguring the possessive relation to them. 'Our things in our hands must be equals, ${ }^{15}$ wrote Alexandr Rodchenko in 1925 . Equally apposite in this context is the contemporary set of theories that goes under the name of Object Oriented Ontology, with their fantasies of a 'parliament of things' or 'democracy of objects, ${ }^{16}$ to borrow the expressions of two important theorists, as well as notions of 'vibrant matter' ${ }^{17}$ and the view that nonhuman forces are active participants in the construction of reality, decentring the subject. Yet it may be more precise and germane to think of Lee's work in relation to what, in Japan, is known as mono no aware, an expression that is translated variously as 'the pathos of things,' 'the awareness of things,' or even 'the ahness of things.' This was the argument made by Sawaragi Noi in an essay titled 'Nameless beyond Namelessness: Why Mono?', where the

\footnotetext{
${ }^{13}$ Marx, Capital, op cit, p 163

${ }^{14}$ Suga cited in Akira Tatehata, 'Mono-ha and Japan's Crisis of the Modern', Third Text, 16:3, 2002, p 236.

${ }^{15}$ Alexandr Rodchenko, cited in Christina Kaier, 'Rodchenko in Paris', October, vol 75, winter, 1996, pp 3-35, p 3

${ }^{16}$ See, respectively: Bruno Latour, We Have Never Been Modern, Catherine Porter, trans, Harvard University Press, Cambridge, Mass. 1993, and L. R. Bryant, The Democracy of Objects, Open Humanities Press

${ }^{17}$ Jane Bennett, Vibrant Matter: A Political Ecology of Things, Duke University Press, Durham, N.C., 2010
} 
critic observed how, as in mono no aware, the stress in Mono-ha is placed on affective experience rather than cognitive understanding, an experience whose origin cannot be ascribed to either subject or object, organism or environment, but rather to the relations between them. Unlike the experience of the commodity, moreover, the form of empathy at stake in mono no aware is related to the experience of transience and mutability, and to the consciousness, if only momentary, of things as they might be were they not under the spell of a possessive ego. This is what distinguishes the experience of mono no aware from literary tropes such as pathetic fallacy, where a development in plot or change in a character's mood transform the surrounding atmosphere. Likewise, there is no such narcissism to an encounter with Lee's works, which do not presume a relationship to things where there is an active relationship on one side, that of the subject, and passive on the other, that of the object, but where the relationship assumes instead the character of a concordance, even of a cooperation.

Lee's Relatum series is often described in terms of the transcendental, and it is true that the works seem to stand aloof from the restlessness of everyday life. Yet the word tends to be used without qualification, and it does little to account for the emphatically material character of his works, which, especially when displayed outdoors, are open to the effects of an ever-changing environment: the steel slowly rusts, while the mirrors reflect the passage of time. Nor does it account for the way in which the movements of the spectator's body alsoand necessarily — unfold in both space and time. The same might be said for Lee's paintings, where the various strokes inscribe the works in both a spatial and temporal register. Claims that the works open onto a timeless space tend to be followed by the assertion that their experience is immediate, that they allow for what one critic has described as 'a direct phenomenological experience of matter and existence. ${ }^{18}$ This may be so. Yet such claims to

\footnotetext{
${ }^{18}$ Alexandra Munro, Lee Ufan: Marking Infinity, The Solomon R. Guggenheim Museum, New York, 2011, n p
} 
transcendence and sensual immediacy ignore the tensions between the contingencies of perception and the experience of timelessness, while also overlooking the highly theatrical and choreographic nature of Lee's work. Michael Fried famously critiqued the Minimalist object for its theatricality and anthropomorphism. ${ }^{19}$ (Fried is an arch-formalist for whom there was, and remains, nothing more impure to art than theatre.) Lee's works seem to court this tendency: Rocks and steel plates behave like protagonists, 'actors' on a stage, to recall the artist's term. There are also moments of illusionism, almost Baroque, that throw into question the nature of the reality that is encountered: Shadows of rocks are sometimes painted onto the floor in a kind of trompe l'oeil, for example, transferring to art the function of nature while also dissolving its metaphysical meaning - the 'Ah!' of awareness is triggered by artifice, not nature. Whether the experience of the works can on this basis be understood as immediate or transcendent is unclear. Things are not experienced as such. It may be more accurate to say that the artworks mimic or emulate those conditions. Rocks and steel plates are turned into symbols of themselves; they are mediated and expressed in artistic form, which contains a transcendent impulse. This suggests the presence of a kind of fracture in the situations the works produce, which may begin to account for their nostalgic character, a point returned to. The paradox that must now be accounted for, however, is that it is through a heightened sense of theatricality and artfulness that the works in the Relatum series invoke a condition that might best be described as immediate, neutral, perhaps artless.

In his final seminars published under the name of The Preparation of the Novel (1978-1980), Roland Barthes developed his exploration of what he called 'figures of the neutral,' figures in which binary modes of thinking are elided in favour of nuance, and where symbolic forms are emptied of content. He found an expression of such a figure in, for example, Bunraku, a traditional form of Japanese puppet theatre where the sources of

\footnotetext{
${ }^{19}$ See especially Michael Fried's essay 'Art and Objecthood', Artforum 5, no 10, June 1967
} 
theatricality are 'exposed in their emptiness. ${ }^{, 20}$ Evacuated from the stage is what Barthes calls 'hysteria, i.e., theatre itself.' ${ }^{21}$ By this he means realism or naturalism and their purported exposure of psychological interiority, which turns the spectator into both voyeur and judge: 'the space is theological,' he writes, 'a space of Guilt.' ${ }^{22}$ In Bunraku, a form of redemption takes place, since only the action necessary to the production of the spectacle occurs. Subjectivity dissolves in the act, while drama reveals itself as such. But it is perhaps above all in the poetic form of the Haiku that Barthes found an exemplary figure of the neutral. There are three reasons for this. The first is related to the genre's use of metrical constraints, which makes the production of a Haiku comparable to the playing of a board game, where only so many combinations are possible. This constrains the role of the ego in the process of making. The second is that the juxtaposition of incongruous images in a poem such as this one, by Bashō,

The winter wind blows

The cat's eyes

Blink, is neither 'antithetical, metonymic [nor] causal. ${ }^{, 23}$ Yet if the Haiku is 'without logic,' Barthes writes, it does not 'signify the destruction of logic, ${ }^{24}$ as is often case with the poetic forms of the Western European avant-garde, such as Dada. The third, related reason is that, for Barthes, the Haiku comprises a form of poetry that functions with a view to obtaining a flat and groundless language that unravels the layers of meaning typically found in symbolic

\footnotetext{
${ }^{20}$ Roland Barthes, Empire of Signs, Richard Howard, trans, Cape, London, 1983, p 59

${ }^{21}$ Ibid, p 62

${ }^{22}$ Ibid, p 61

${ }^{23}$ Roland Barthes, The Preparation of the Novel: Lecture Courses and Seminars at the Collège de France (1978-1979 and 1979-1980), Kate Briggs, trans, Columbia University Press, New York, 2011, p 31

${ }^{24}$ Ibid, p 31
} 
forms, what he calls elsewhere the 'lamination' 25 of symbols. In a Haiku such as this one, again by Bashō,

I come by the mountain

Ah! this is exquisite!

A violet!

or this one, by the same poet,

Already four o'clock...

I have got up nine times

To admire the moon,

Barthes finds an antidote or panacea to 'the obsessional play of symbolic substitutions ${ }^{26}$ that characterises much of Western poetic diction and metaphysics, together with the kinds of interpretation or critique these symbolic forms demand, which implicitly place the interpreter in a position of knowledge. In the Haiku, there is no symbolic content to be deciphered or hidden depths to be revealed. Instead, what the reader experiences is an exemption from, and absenting of, meaning, a form of neutrality, even as the poems remain perfectly intelligible. In this way, Barthes writes, 'the Haiku diminishes to the point of pure and sole designation. It's that, it's this, says the haiku, it's so. Or better still: so!'27

What Barthes encounters in the Haiku bears on the experience of the works in Lee's Relatum series, which, in their different ways, also approach a condition of flatness and neutrality, and where there is no known object or knowing subject, but rather an experience that is transitive and interstitial. The works do not constitute objects of cognition but 'responsive fields, ${ }^{, 2}$ in Lee's expression. It is as though the spectator encountered the works

\footnotetext{
${ }^{25}$ Barthes, Empire of Signs, op cit, p 4

${ }^{26}$ Ibid, p 75

${ }^{27}$ Ibid, $\mathrm{p} 83$

${ }^{28}$ Lee Ufan, The Art of Encounter, op cit, p 30
} 
in question like the speaker in Bashō's poems, or indeed like one of their readers, and here too the 'Ah!' of recognition, both precisely situated and highly individuated, is neither possessive nor sadistic. There is no hidden meaning beyond the phenomenal existence of the elements and the relations they set in play, no secret to be grasped or penetrated. Instead, meaning is absented, exempted, as is the related need for forms of critique that sometimes border on the paranoid — hence what used to be called the "hermeneutics of suspicion. ${ }^{29}$ If rocks and steel behave like actors in a play, then it is a play in which the theatrical elements are laid bare. As with Bunraku puppet theatre, there is an absence of duplicity - the painted shadows point to themselves as painted shadows, the rocks and steel become symbols of what they might be - while the hysterical and theological aspects Barthes finds in dominant forms of Western dramaturgy are dissolved, together with their attendant Guilt. For such reasons, the various elements in the Relatum series could be said to share the elegance and affectation of the marionette, which is not only true of Bunraku, but also of certain European traditions. For example, in Heinrich von Kleist's famous essay on the marionette theatre, published in 1810, the writer elaborates a mechanistic notion of dance that works against the naturalistic expression of emotions, and suggests that the marionette, in its affectation, has achieved a state of grace. This is because, for Kleist, the marionette exists at the intersection of the artificial and the artless; half mechanical and half god, in the marionette's impersonal dance the infinite finds expression in the finite. ${ }^{30}$ It is consciousness, or self-awareness, that prevents the human subject from reaching such a state. That at least is the fiction the essay sets in train.

It was previously held that the commodity could be considered a fetish object. This is true both economically and sexually, the Surrealist found object or trouvaille, with its

\footnotetext{
${ }^{29}$ The expression was coined by the philosopher Paul Ricoeur.

${ }^{30}$ See Heinrich von Kleist, 'On the Marionette Theatre', The Drama Review, TDR, vol 16, no 3, 1972, pp 22-26
} 
invocation of a veiled, concealed, or displaced meaning, being in this respect paradigmatic of a particular experience of capitalist modernity and urban life, one that arguably finds its beginnings in the nineteenth century Parisian arcades. The commodity can also be described as a schizoid object because its identity is split in two, its material body reduced to a contingent expression of its exchange-value. ${ }^{32}$ In the Relatum series, such forms of pathology—hysteria, fetishism, schizophrenia, paranoia—are dramatically attenuated, if not suspended. Theatricality is exposed in its emptiness, as is the lamination of symbols. On this view, the function of mirrors in the series may be exemplary. They do not serve to affirm, narcissistically, what conventionally goes under the name of the self, but reflect the world in its almost infinite mutability while retaining nothing of it. They are 'the symbol[s] of the very emptiness of symbols, ${ }^{33}$ to borrow Barthes' definition. The same might be said for gesture in Lee's paintings, where each stroke does not refer back to a self, but only to what the cultural theorist calls a 'graphic mode of existing' 34 in which the self is effaced, the strokes of paint sharing instead the designatory character of a Haiku: So! This also has implications for how the function of repetition in the paintings is experienced and understood. Lee's method, his style, appear free from excess and compulsion, the form of automaticity at stake having less to do with what, in the language of psychoanalysis, are called the drives - though these may remain, perhaps necessarily, at work - than with an attempt to eclipse the subject through ritual and process.

Barthes' interest in the category of the neutral, together with Japanese cultural productions more broadly, may risk a certain Orientalism. The same may be true of the present reading of Lee's work. So it is worth mentioning here that Barthes' Japan constitutes

\footnotetext{
32 'The commodity', as Terry Eagleton has put it, 'is a schizoid, self-contradictory phenomenon, a mere symbol of itself, an entity whose meaning and being are entirely at odds and whose sensuous body exists only as the contingent bearer of an extrinsic form.' Eagleton, cited in Sven Lütticken, 'Attending to Abstract Things,' New Left Review 54, November - December 2009, p 101

${ }^{33}$ Barthes, Empire of Signs, op cit, p 79

${ }^{34}$ Ibid, p 80
} 
what he calls a 'novelistic object,' that is to say, a fiction. It is a fiction that finds its roots in visits to the country but also in the work of Zen writers such as D. T. Suzuki and Alan Watts, as well as in the fin-de-siècle writings of Marcel Proust, a consistent point of reference in his work. For Proust, as for Barthes, Japan allowed for a different worldview to be imagined, a counter-system of signs that favoured the fugitive and impressionistic and which, in its reconfiguration of art's relationship to nature, offered alternative ways of being and seeing to those dominant in the West, which tend to posit an unbridgeable gap between subject and object. In the Recherche, the first edition of which was printed in 1908 on Japanese paper, it is part of both the narrator Marcel and the painter Elstir's apprenticeships to learn how to see the world through the lens of an imagined Japan's aesthetic productions. Thus, at Martinville, it is through the Japonist image of a blossom tree silhouetted against the horizon at dusk that Marcel begins to observe how things exceed their outlines and merge with their surroundings. Nor is it likely to be by chance that the most famous instance of involuntary memory in the Recherche, the episode of the madeleine, should be described in the same breath as a child's game played in Japan in which small pieces of paper are soaked in a porcelain bowl filled with water until they blossom into 'flowers or houses or people, solid and recognisable. ${ }^{35}$ It is in this same way that the past is released into the narrator's cup of tea, brought to consciousness through metaphor and lent reality in art; and it is because of such evocative, metamorphic, almost dream-like experiences - reverie is perhaps the most adequate word to describe the state of mind here, or maybe that of a child daydreaming, like Lee's granddaughter in the aforementioned photograph — that some have seen in Proust's writings

\footnotetext{
${ }^{35}$ Marcel Proust, Remembrance of Things Past: Swann's Way, C. K. Scott Moncrieff, trans, Penguin, London, 1997, 64
} 
an aesthetic close in kind to that associated with mono no aware, the pathos of things, the awareness of things, or the ahness of things. ${ }^{36}$

Proust is also an explicit point of reference in Lee's work; one iteration of the Relatum series, a curved steel bar that rests gently on a rock, is called Relatum-Lost Time (2005). To imagine the artist's aesthetic as constituting a form of Japonism akin to Proust's may be fitting given his own position as a Korean artist living between Japan and France. This touches on Lee's own experience of rootlessness, as well as his anxiety at having left Korea for Japan a little more than a decade after the end of a colonial occupation whose legacies were, and remain, highly contentious. ('I do not exist in Japan', the artist has said, 'and if I go to Korea, I cannot confirm for myself a definite reality. ${ }^{37}$ ) It also invites another way of seeing his work's ideography: the blue strokes of paint in the From Line series, for instance, evoke Vincent van Gogh's Irises (1889) as much as they do Ogata Kōrin's (c.1701), while the large empty spaces in his later Dialogue paintings call to mind Cage's and Takemitsu's silences as much as they do Japanese $m a$, where the intervals between things are felt as active, not passive. But the reference to Proust is perhaps most important because it helps to make sense of the difficult problem of memory in Lee's work and its relation to affect.

The experience of walking among the rocks and steel plates in the Relatum series might be compared to the narrator's many encounters with things in the Recherche and the involuntary memories they trigger. This is true of the madeleine soaked in tea, but also of the shape of a roof, the gleam of the sun on a stone, or the odour of a path, to provide just a few examples, which induce in the narrator a kind of free-floating attention, or perhaps inattention, akin to reverie: 'they had seemed to me to be full, ready to unfurl themselves, to

\footnotetext{
${ }^{36}$ See, for instance, Jan Hokenson, 'Proust's 'Japonisme': Contrastive Aesthetics', Modern Language Studies, vol 29, no 1, 1999, pp 17-37

${ }^{37}$ Lee, cited in Kee, 'Points, Lines, Encounters', op cit, p 413
} 
hand over to me that of which they were only a covering. ${ }^{38}$ It is as if the world in such moments became animated, expressive, even enchanted. Likewise, in the Relatum series, inanimate things take the shape of recognisable characters, like pieces of paper blossoming in a porcelain bowl, the difference being one of scale. Such a communion with the inanimate is not one-sided, however. To say that things in Lee's work become expressive and evocative through a form of projective identification would tell only one half of the story, since the subjective experience of the works contains an objective moment, without which the spectator, like Proust's narrator, or indeed the speaker in Bashō's poems, could not be drawn towards things or hear their call. It is not only that "physical stimuli $[\ldots]$ add to the dreams of the imagination the concept of "existence" that they usually lack, ${ }^{39}$ as Marcel puts it in Time Regained, but that, as the narrator was also acutely aware, those dreams are inscribed and persist in things. In the absence of this objective moment, any sense of continuity between subject and object in the Relatum series would be precluded, the latter being no more than a projection of the former. Yet this is not the case. Through a form of mimesis or empathetic identification, the subject is constituted, or comes into being, in the same way as the other elements or actors on stage: relationally, laterally, neutrally, in a field of reciprocity, as a thing among things. The paradox is that this proximity to the nonhuman, the experience of becoming as thing-like as a stone or of a stone becoming as alive as a person, is achieved not by the destruction of culture or by a return to nature — one does not encounter things as such any more than one experiences one's own body as such—but by raising both people and things into the sphere of the aesthetic. It is in this respect that Lee's work is closest to Proust, where mute things speak and where the distinction between animate subjects and inanimate objects is often confused.

\footnotetext{
${ }^{38}$ Proust, Swann's Way, op cit, pp 251-252

${ }^{39}$ Marcel Proust, In Search of Lost Time: Time Regained, vol 6, p 905
} 
Towards the end of the seminars collected in The Preparation of the Novel, Barthes cites the following Haiku by Busson:

What happiness,

Crossing this river,

Sandals in hand!

He explains his reasons for citing the poem as subjective. He is almost certain that he has lived this moment, in his childhood, perhaps in Morocco, after a summer picnic, the Haiku thus provoking in him an intense and particular pleasure, which is followed by a sense of loss. Barthes goes on to observe that there is a congruence between the Haiku and involuntary memory, the difference being that the Haiku tends towards an extreme compression, a form proper to the brevity of the event expressed, while the object of involuntary memory, like the Proustian sentence, unfolds, extends, and dilates, inclining towards infinity: 'The madeleine is a Japanese flower in water,' he writes, 'the Haiku is a flower without water; a flower that remains budded. ${ }^{40}$ That Barthes should have encountered, involuntarily, a childhood memory in a Haiku's solicitation suggests that the poem's mnemonic function is always in excess of individual memory. This is especially true of forms of voluntary memory, which constitute acts of will and exist in the domain of intellect, not of affect or sensory experience. It is perhaps in this way that one can understand Lee's own concerns with infinity. Like a Haiku, the Relatum series anchors the experience the body in the here and now. Yet this sense of continuity between subject and object, this sense of becoming in some way like the work, is only achieved through the mediation of artistic form, even if one is never quite sure where art ends and the world begins. In Relatum - Holzwege II (2010), for example, it is possible to walk past the rocks and steel plate without

\footnotetext{
${ }^{40}$ Barthes, The Preparation of the Novel, op cit, p 39
} 
noticing them; they almost merge with the surrounding forest. The encounter or Ah! of recognition takes place, if it does, almost as if by chance.

The objective dimension to involuntary memory adds a further complication to how the nostalgic character of the Relatum series is understood. There seems always to be an unaccountable familiarity to the works, a sense of something forgotten almost within reach, even as the elements, including one's own body, seem for a while to inhabit a world slightly different from one's own, or perhaps a different story, even if its constituent parts remain thoroughly of this world. Yet if a work such as Lost Time recalls a time that is lost, if the work repeats that time, lends it shape and solidity in artistic form, then it is an experience that is mediated by the memory of what has not yet taken place, since the relations staged and enacted in the work are foreclosed by the present state of things. Lost Time thus 'reminds us of what has never happened to us; in it we recognize a repetition without origin, an event without cause, a memory without person, a language without moorings, ${ }^{41}$ to use Barthes's description of the Haiku - a description, parenthetically, which could just as well describe the object of involuntary memory: 'real without being actual, ideal without being abstract," ${ }^{42}$ as the narrator puts it. As in a play of mirrors, the symbols are empty, and it is this emptiness that allows them to be seen with impersonal clarity and which lends their experience a ritual perfection. It is as though the object of art had for a moment become reconciled with its own image. This may be what lends Lost Time the semblance, and only the semblance, of transcendence. The work might then be said to exist in the register of the 'what if': like an archaeology of the future, Lost Time contains a symbolic element beyond that afforded by reality, allowing us to reflect upon the reified, possessive, perhaps sadistic, relations between subjects and objects in the present. It is true that the 'what if' has a tendency to slide into the

\footnotetext{
${ }^{41}$ Barthes, Empire of Signs, op cit, p 79

${ }^{42}$ Proust, cited in Gilles Deleuze, Repetition and Difference, Paul Patton, trans, Continuum, London, 2004, p 94
} 
'if only,' a kind of wishful thinking made up of the memories of a life not lived, but then what more could one ask of steel, rocks, and mirrors, or indeed of art, which itself could have looked very different had its histories unfolded in a different way? As with the other works in the Relatum series, Lost Time might on this basis be seen to constitute a preparatory study or propaedeutic, rather in the same way that the narrator of Proust's Recherche only begins to write once the narrative is concluded. That the novel describes an apprenticeship, that its function is to prepare a place for a future book — one might talk about a difference, or perhaps a fracture, between the actual novel and the virtual novel—suggests that, as important as the existing work, which explores, among other questions, what it means to live after loss and so is oriented towards the past, is the work that is to come. When seen from this perspective, the sense of longing that underpins the Relatum series does not comprise a nostalgia for the past—Lee's works are not reactive; they do not hark back to a purer, because unmediated, time (the presence of industrial materials precludes such a reading)—but, paradoxically perhaps, a nostalgia for the future, a promise of happiness whose likeness is recalled in art. 
